\title{
Use of nanosystems to improve the anticancer effects of curcumin
}

\author{
Andrea M. Araya-Sibaja ${ }^{1,2}$, Norma J. Salazar-López ${ }^{3,4}$, Krissia Wilhelm Romero ${ }^{1,5}$, \\ José R. Vega-Baudrit ${ }^{1,6}$, J. Abraham Domínguez-Avila ${ }^{7}$, Carlos A. Velázquez Contreras ${ }^{8}$, \\ Ramón E. Robles-Zepeda ${ }^{8}$, Mirtha Navarro-Hoyos ${ }^{5}$ and Gustavo A. González-Aguilar ${ }^{* 3}$
}

\section{Review}

Address:

${ }^{1}$ Laboratorio Nacional de Nanotecnología

LANOTEC-CeNAT-CONARE, 1174-1200, Pavas, San José, Costa

Rica, ${ }^{2}$ Universidad Técnica Nacional, 1902-4050, Alajuela, Costa

Rica, ${ }^{3}$ Laboratorio de Antioxidantes y Alimentos Funcionales, Centro

de Investigación en Alimentación y Desarrollo (CIAD), A.C.,

Hermosillo, Sonora 83304, México, ${ }^{4}$ Universidad Autónoma de Baja

California, Facultad de Medicina de Mexicali, Lic. en Nutrición, Dr.

Humberto Torres Sanginés S/N, Centro Cívico, Mexicali, Baja

California 21000, México, ${ }^{5}$ Laboratorio BioDESS, Escuela de

Química, Universidad de Costa Rica, San Pedro de Montes de Oca

2060, San José, Costa Rica, ${ }^{6}$ Laboratorio de Investigación y

Tecnología de Polímeros POLIUNA, Escuela de Química,

Universidad Nacional de Costa Rica, Heredia 86-3000, Costa Rica,

${ }^{7}$ Cátedras CONACYT-Centro de Investigación en Alimentación y

Desarrollo A. C., Hermosillo, Sonora 83304, México and ${ }^{8}$ Unidad

Regional Centro, Departamento de Ciencias Químico-Biológicas y de

la Salud, Universidad de Sonora, Hermosillo, Sonora 83000, México

Email:

Gustavo A. González-Aguilar ${ }^{*}$ - gustavo@ciad.mx

* Corresponding author

Keywords:

nanocarrier; nanoformulations; nanosized delivery systems; phenolic

compounds

\author{
Beilstein J. Nanotechnol. 2021, 12, 1047-1062. \\ https://doi.org/10.3762/bjnano.12.78 \\ Received: 13 February 2021 \\ Accepted: 23 August 2021 \\ Published: 15 September 2021 \\ Associate Editor: A. Salvati \\ (C) 2021 Araya-Sibaja et al.; licensee Beilstein-Institut. \\ License and terms: see end of document.
}

\begin{abstract}
Curcumin (CUR) is a phenolic compound that is safe for human consumption. It exhibits chemopreventive, antiproliferative, antiangiogenic, and antimetastatic effects. However, these benefits can be hampered due to the lipophilic nature, rapid metabolism, low bioavailability, and fast elimination of the molecule. Considering this, the present work reviews the use of CUR-based nanosystems as anticancer agents, including conventional nanosystems (i.e., liposomes, nanoemulsions, nanocrystals, nanosuspensions, polymeric nanoparticles) and nanosystems that respond to external stimuli (i.e., magnetic nanoparticles and photodynamic therapy). Previous studies showed that the effects of CUR were improved when loaded into nanosystems as compared to the free compound, as well as synergist effects when it is co-administrated alongside with other molecules. In order to maximize the beneficial health effects of CUR, critical factors need to be strictly controlled, such as particle size, morphology, and interaction between the encap-
\end{abstract}


sulating material and CUR. In addition, there is an area of study to be explored in the development of CUR-based smart materials for nanomedical applications. Imaging-guided drug delivery of CUR-based nanosystems may also directly target specific cells, thereby increasing the therapeutic and chemopreventive efficacy of this versatile compound.

\section{Introduction}

According to the International Agency for Research on Cancer, approximately 9.5 million people worldwide die annually from malignant neoplasms [1]. Deaths are primarily due to cancer of the respiratory system $(17 \%)$, liver $(10 \%)$, colon and rectum $(8 \%)$, breast (8\%), and stomach (8\%) [2]. The most commonly used treatments involve chemotherapy, surgery, or a combination of both. Chemotherapy is based on the use of molecules such as doxorubicin, paclitaxel, cisplatin, and some proteins and peptides that induce cell death [3]. Conventional or low molecular weight chemotherapeutics remain one of the most common treatment options. Each specific compound will have a particular mechanism of action (alkylating agents, topoisomerase inhibitors), but they all mainly target rapidly dividing cells. However, most tend to be non-specific, thus, they are distributed indiscriminately to all normal and abnormal cells [4], which leads to systemic toxicity that triggers hair loss, loss of appetite, immunosuppression, and inflammation [3]. These side effects can be severe enough to significantly impact the efficacy of a given treatment, while also causing high patient discomfort [5]. Low drug solubility, lack of specificity, high toxicity, poor therapy index, and multidrug resistance are other related drawbacks [6,7]. Orally administered chemotherapy is currently unsuitable due to the low bioavailability of chemotherapeutic agents [8], making intravenous the only viable route of administration, since it avoids bioavailability issues. However, this results in increased toxicity and side effects [3].

Therefore, one of the goals of new and/or improved cancer therapies is for the drug to only target malignant cells in sufficient concentrations and with minimal distribution to other tissues to avoid adverse effects as much as possible. Nanomedicine has recently emerged as an option for cancer treatments and the rationale for its use is based on various improvements seen when a nanosized material and/or drug is administered. It has been successfully used during diagnosis when controlled drug administration is required and for regenerative medicine $[9,10]$ although new applications are constantly being developed. Some of the main advantages of nanosized drug administration include an improved pharmacokinetic profile, higher selectivity towards tumor cells, and increased cellular and organelle internalization, as compared to conventional therapies, potentially increasing therapeutic efficacy and minimizing side effects [4]. Nanosystems can be referred to as nanocarriers, nanoformulations, nanosized-delivery systems, and other similar terms. They have been utilized in the design of cellular and subcellular anti- cancer therapies which carry the drug and better focus it on the intended target. They are also able to contain molecules that respond to endogenous (tumor microenvironment, including redox potential, $\mathrm{pH}$, enzymes, ions, or biomolecules) and/or exogenous stimuli (light, electromagnetic fields, or ultrasound) $[11,12]$. Since exogenous stimuli are precisely controlled by the researcher, they can be used to optimize cellular delivery and dose, thus, they will be the main focus of the present work. However, it should be mentioned that those that respond to exogenous stimuli do have some disadvantages, such as the need for additional instrumentation to generate electromagnetic or ultrasonic waves, which may increase their cost and/or complexity.

Curcumin (CUR) or diferuloylmethane is a phenolic compound extracted from turmeric (Curcuma longa) rhizomes. It is safe for human consumption [13] and is known for its potentially beneficial health effects $[14,15]$. Searching for peer-reviewed publications using the term "curcumin" in PubMed, ScienceDirect, and Scopus published during 2010-2020 results in 34.4, 20.4 , and 26.6 thousand publications, respectively, of which $74.6 \%, 62.4 \%$, and $33.4 \%$ are cancer-related papers.

The beneficial effects of CUR as an anticancer agent is derived from its chemopreventive [16], antiproliferative [17], antiangiogenic [18] and antimetastatic capabilities [19]. Unfortunately, these benefits can be minimized due to the lipophilic nature, rapid metabolism, low bioavailability, and fast elimination of the molecule $[13,20,21]$. Thus, research has been focused on incorporating CUR into nanosystems, potentially maintaining or improving its effects on biological systems. The present work reviews the use of CUR-based conventional nanostructured systems used to improve CUR anticancer activity, including liposomes, nanoemulsions, nanocrystals, nanosuspensions, and polymeric nanoparticles, as well as dual effect nanosystems which respond to external stimuli (mainly magnetic nanoparticles and photodynamic therapy), in addition to internal ones. Furthermore, key design factors that could impact the performance of CUR-based nanosystems as a cancer therapy option are also considered. Due to the large body of evidence supporting the bioactivity of CUR, it has been widely considered a suitable molecule to be encapsulated in order to increase and target its delivery. The evidence on this regard was reviewed by Naksuriya et al. [22]. Furthermore, it should be noted that the anticancer bioactivity of CUR is preserved when the parent 
compound is modified into derivative compounds, such as dimethyl CUR, metal-CUR complexes, tetrahydrocurcumin among others [23].

According to this information, the aim of the present work is to summarize the improvements regarding anticancer effects obtained when CUR is encapsulated using various nanosized systems.

\section{Review}

\section{Curcumin in cancer therapy}

Figure 1 summarizes the effects of CUR on cancerous processes, according to information generated from clinical trials. In vitro studies have revealed that the anticancer effects of CUR are mainly due to proapoptotic and antiangiogenic actions, which are regulated by different cell signaling pathways, such as Wnt/ $\beta$-catenin, PI3K/Akt, JAK/STAT, MAPK, p53, and $\mathrm{NF}-\mathrm{KB}$ [24]. Tumor growth and metastasis are highly dependent on angiogenesis [25], making this process a likely target to prevent, mitigate, or treat some types of cancer. Previous studies have reported the antiangiogenic activity of CUR against cancerous cells $[26,27]$. In fact, CUR has been shown to hinder proliferation and invasion of non-small-cell lung cancer through the regulation of metastasis-associated protein 1 (MTA1), which is linked to tumor aggressiveness and metastasis, while its modulating effect is related to the suppression of the Wnt/ $\beta$-catenin pathway. Curcumin also blocks pancreatic cancer metastases through $\mathrm{PI} 3 \mathrm{~K} / \mathrm{Akt} / \mathrm{NF}-\mathrm{kB}$ pathway and induces an antiangiogenic effect in laryngeal squamous cell carcinoma.
The antiangiogenic effects of CUR may be associated to an inhibition of JAK-2 expression, production of pSTAT-3, and decrease in MMP-2 and VEGF, all of which are key vascularization factors. Curcumin also exerts a proapoptotic effect through its interaction with multiple molecular targets, including caspases (3, 9, and 8), Apaf1, PARP, Bax, Cyto-C, PUMA, MCL-1, and Survivin, while also suppressing the expression of

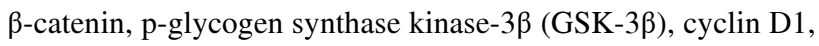
c-myc, and the PI3K/Akt/mTOR pathway [24]. In addition to the previous data, it should be stated that coadministration of CUR with another anticancer molecule may also serve to complement or potentiate its effects. The use of a single delivery system will also normalize any differences in the pharmacokinetics of co-encapsulated drugs that are due to different rates of absorption and metabolism, thus, better responses may be achieved [18,39].

\section{Curcumin nanosystems in cancer therapy}

Nanotechnology can improve the effects of conventional chemotherapeutic agents by reducing multidrug resistance, personalizing cancer treatment, decreasing toxicity, and extending product life cycles [7]. Moreover, they can enhance the therapeutic index and pharmacokinetics of several compounds [40]. This is due to their nanoranged size and the possibility of modifications that can make them able to cross biological barriers to reach a specific target organ, cell, or organelle, improving solubility, dissolution rate, and pharmacokinetics [5].

In the case of CUR, the nanosystem size directly influences its biodistribution as demonstrated by Bi et al. [41], who reported

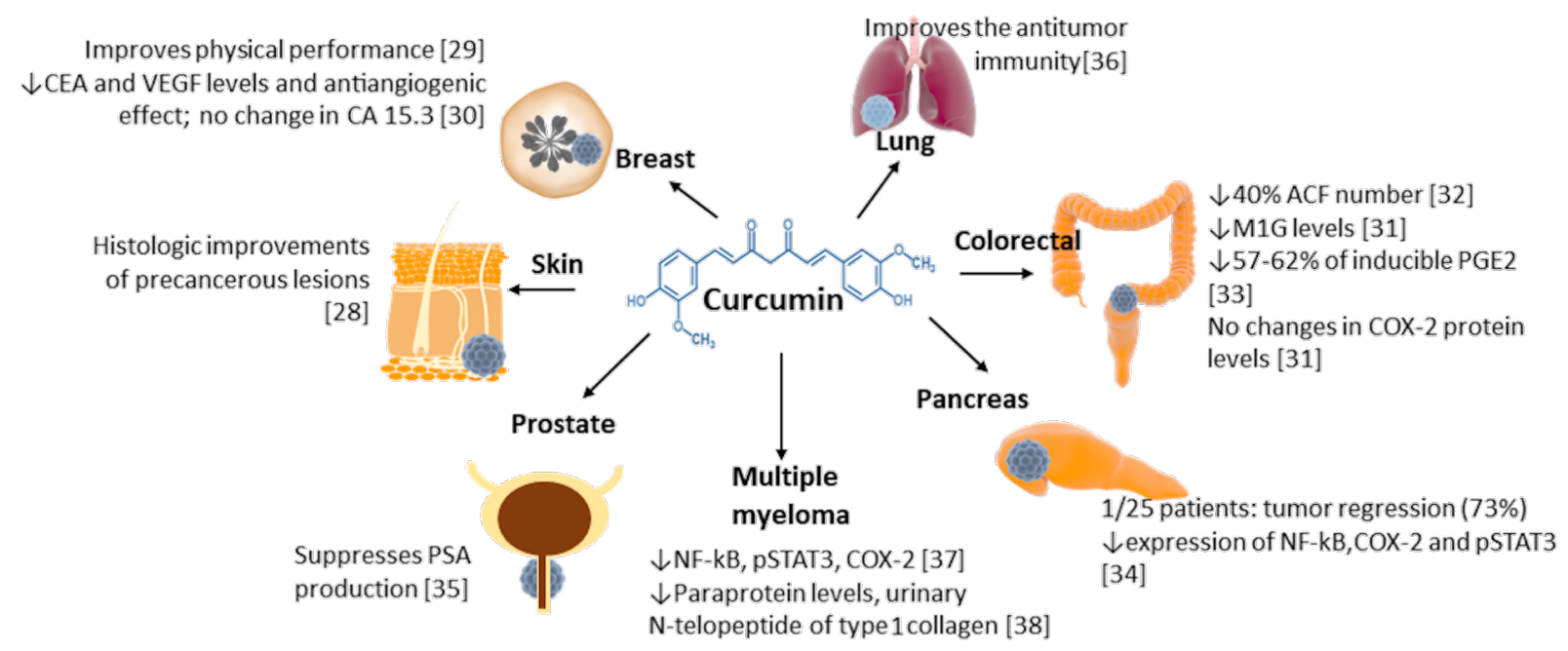

Figure 1: Effects of CUR on cancerous processes observed on clinical trials [28-38]. Carcinoembryonic antigen (CEA); vascular endothelial growth factor (VEGF); cancer antigen 15.3 (CA15.3); DNA adduct 3-(2-deoxy- $\beta$-di-erythro-pentafuranosyl)pyrimido[1,2- $\alpha$ ]purin-10(3H)-one (M1G); enzyme cyclooxygenase-2 (COX-2); colorectal aberrant crypt foci (ACF); prostaglandin E2 (PGE2); 5-hydroxyeicosatetraenoic acid (5-HETE); phosphorylated signal transducer and activator of transcription 3 (pSTAT3); monoclonal gammopathy of undetermined significance (MGUS); nuclear factor kappa B (NF-kB). 
differences in the pharmacokinetic profiles when they administered CUR nanosuspension of different sizes $(20,70$, or $200 \mathrm{~nm}$ ). For example, maximum plasma CUR concentration was found 5 min after administration (with concentration of $1250 \mathrm{ng} / \mathrm{mL}$ and particle size of $20 \mathrm{~nm}$ ). In the lungs, spleen, and liver the maximum concentration was observed $10 \mathrm{~min}$ after administration (with concentrations and particle sizes of $800 \mathrm{ng} / \mathrm{mL}-70 \mathrm{~nm}, 280 \mathrm{ng} / \mathrm{mL}-200 \mathrm{~nm}$, and $550 \mathrm{ng} / \mathrm{mL}-200 \mathrm{~nm}$, respectively). In the brain, the maximum CUR concentration was detected $5 \mathrm{~min}$ after administration $(20 \mathrm{ng} / \mathrm{mL}$ with a particle size of $20 \mathrm{~nm}$ ). This suggests that targeted delivery via an optimized size can lead to an increased organ concentration, making it another important benefit of this nanoscale-based approach. However, it is also possible that the bioactive compound may be instead accumulated in other organs at the same time, not just in the brain. This less specific pharmacokinetic profile could be a disadvantage, since targeting only a particular tissue or organ may not be entirely feasible, thereby causing dosage uncertainties when administering the treatment, which should be taken into account. Thus, there is still room to improve these types of nanosystems, and/or to develop additional ones [42].

\section{Conventional nanosystems}

Conventional nanosystems are particularly attractive for the biopharmaceutics classification system (BCS) class IV drugs, such as CUR, which require increases in their solubilization, pharmacokinetics, and permeation [43]. Curcumin has been targeted against carcinogenic lesions in the colon, skin, cervix, pancreas, prostate, breast, head, and neck [44]. These nanosystems can be lipid-based or polymeric and can contain CUR by itself or in addition to another molecule. General characteristics of these systems and their advantages are described in the following sections. Furthermore, some specific conventional CUR-containing nanosystems that have enhanced therapeutic efficacy are discused.

Nanocrystals, nanococrystals, and nanosuspensions. Nanocrystals are crystalline materials that contain the drug or molecule of interest at the nanoscale, with a size that can range from $10-1000 \mathrm{~nm}$ [45]. They can be produced as a powder or as an aqueous suspension containing only the drug [46]. Some authors refer to nanocrystals as indistinguishable from nanosuspensions [47], which may be due to subtle differences between them (Figure 2). Strictly speaking, a nanosuspension is a colloidal dispersion of pure particles of a drug which is stabilized by the use of surfactants [48]. Therefore, a nanosuspension can be prepared by dispersing a nanocrystal or any other powdered material in an outer liquid medium using a stabilizing agent [45]. Furthermore, these nanosystems have shown increased adhesion to surfaces. The advantages of these systems have been evidenced by the significant increase in the in vivo performance of drugs administered in this way [47]. For instance, CUR nanocrystals obtained by solution-enhanced dispersion via supercritical $\mathrm{CO}_{2}$ showed increased internalization and apoptotic effects in colorectal cancer cells (HCT116) by promoting cell cycle arrest at the G2/M phase [49]. A CUR nanocrystal has been successfully prepared using melt sonocrystallization, in which its therapeutic potential was evidenced according to in vitro cytotoxicity studies against a human oral cancer cell line (KB). The results showed a growth inhibition $\left(\mathrm{GI}_{50}\right)$ value $<10 \mu \mathrm{g} / \mathrm{mL}$, enhanced inhibition of proliferation, and higher cytotoxicity as compared to free CUR (F-CUR) [50]. Hu et al. [51] formulated a nanocrystal with curcumin and yttrium-stabilized zirconium oxide, which maintained the stability of CUR for 60 days (at $25{ }^{\circ} \mathrm{C}$ ) and with a dissolution capacity of $98 \%$ at $4 \mathrm{~h}$ (aqueous solution with $1 \%$ SDS, at $37{ }^{\circ} \mathrm{C}$, and $100 \mathrm{rpm}$ ). Regarding their pharmacokinetics in vivo (rabbits, $25 \mathrm{mg} / \mathrm{kg}$ ), it was observed that when the nanocrystal was administered via endotracheal insufflation, the average maximum concentration $\left(C_{\max }\right)$ and the plasma area under the curve (AUC) were higher $(27.52 \mathrm{mg} / \mathrm{L}$ and $37.25 \mathrm{mg} / \mathrm{L} \cdot \mathrm{h}$, respectively), as compared to the one administered orally (3.64 $\mathrm{mg} / \mathrm{L}$ and $11.75 \mathrm{mg} / \mathrm{L} \cdot \mathrm{h}$, respectively). The value of $T_{1 / 2}$ was $1.46 \mathrm{~h}$ when administered by the pulmonary route and $2.15 \mathrm{~h}$ when administered orally, which could be associated with an improved CUR solubility due to the nanosystem. Furthermore, half an hour after pulmonary administration, CUR concentration values higher than $2000 \mu \mathrm{g} / \mathrm{g}$ were observed in the lungs and $6 \mathrm{~h}$ after pulmonary administration the concentration was $824 \mu \mathrm{g} / \mathrm{g}$. Curcumin was also found in other organs, such as the liver (approx. $40 \mu \mathrm{g} / \mathrm{g}, 0.5 \mathrm{~h}$ ), spleen (approx. $30 \mu \mathrm{g} / \mathrm{g}, 2 \mathrm{~h}$ ), kidneys (approx. $19 \mu \mathrm{g} / \mathrm{g}, 4 \mathrm{~h}$ ), heart (approx. $5 \mu \mathrm{g} / \mathrm{g}, 4 \mathrm{~h}$ ), and brain (approx. $5 \mu \mathrm{g} / \mathrm{g}, 0.5 \mathrm{~h}$ ). This shows that CUR nanocrystals administered by the pulmonary route could be a strategy to increase its concentration and permanence in the plasma and in other organs. It should be noted that in a dose-escalation study in human volunteers, in which $10-12 \mathrm{~g} /$ day of CUR was administered, only $30-50 \mathrm{ng} / \mathrm{mL}$ of curcumin was detected in the serum (between 2 and $4 \mathrm{~h}$ after administration), which is associated with its low solubility, instability at a physiological $\mathrm{pH}$, and rapid metabolization [52].

Although nanocrystals make it possible to improve the solubility of CUR, it has been reported that this type of nanosystem can have certain stability problems, which may compromise the ability to ensure a consistent dosage [53].

Nanococrystals, on the other hand, are a combination of two different approaches that include cocrystal preparation and subsequently the nanonization of the obtained cocrystal [54]. 


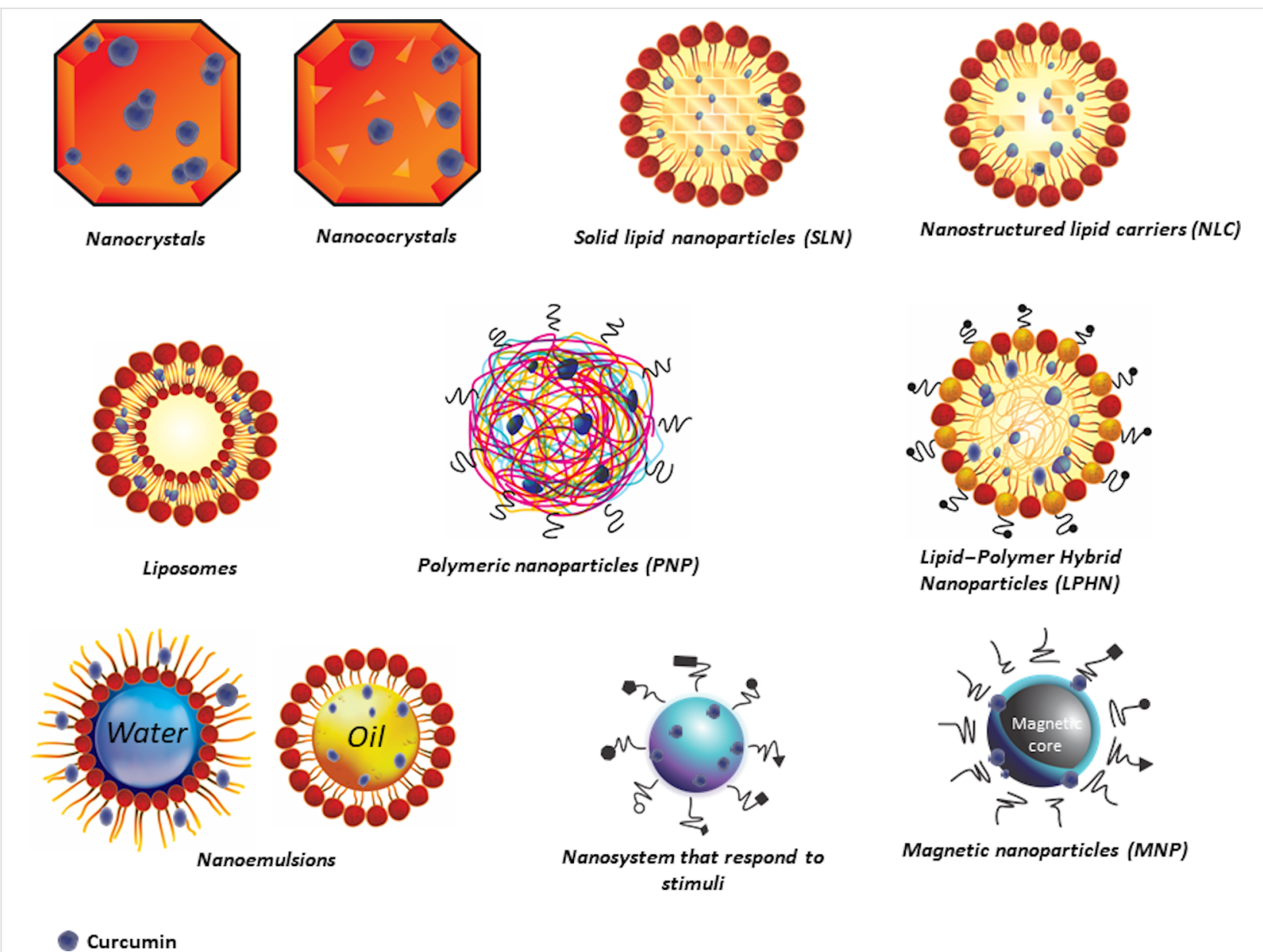

Figure 2: Graphical representation of CUR-based nanosystems. Because of its poor water solubility, CUR will preferentially accumulate in the lipophilic component of the structures, such as the lipid cores or the phospholipids.

The resulting material combines the advantages of cocrystals and nanoscale size to considerably increase solubility, dissolution rate, and bioavailability of the molecules of interest [55]. In addition, as the second molecule in the crystal lattice can also be a bioactive one, their expected effect when used as therapeutic agents can be improved due to their synergic action. This strategy has been used by Ji et al. [56], who modified the surface of CUR nanococrystals with hyaluronic acid to increase its hydrophilicity, which resulted in a better biodistribution. They reported an advantage in the release profile as a function of $\mathrm{pH}$ due to a lower CUR release at $\mathrm{pH} 7.4(40 \%)$ as compared to the acidic $\mathrm{pH}(\mathrm{pH} 5,80 \%)$ which is characteristic of the tumor microenvironment ( $\mathrm{pH}$ 6.5) and subcellular endosomes $(\mathrm{pH}$ 5.0). Regarding its apoptotic effects, a high anticancer activity was found when assayed against a breast cancer cell line (MDA-MB-231), an effect that was accompanied by an enhanced cellular uptake in cells that overexpressed CD44. Besides, they reported complementary evidence in which in vivo studies in female $B A L B / c$ mice showed that CUR nanococrystals had better anticancer effects in a $4 \mathrm{~T} 1$ orthotopic breast cancer model as compared to F-CUR. Ribas et al. [57] reported that supercritical solvents (and no cosolvents) were used to produce their CUR-nicotinamide nanococrystal. The nanosystem showed a higher dissolution rate, in addition to antinociceptive and anti-inflammatory effects.

In contrast to their advantages, cocrystals are not easily obtained. Another option is to formulate a nanoemulsion that contains CUR as the molecule of interest alongside another bioactive entity (i.e., coadministration). Curcumin-piperine nanoemulsion (CUR-PIP) is a great example of this combination approach as a chemotherapy agent against various types of cancer. Piperine has been shown to act as a bioenhancer molecule that improves the solubility CUR while exerting no in vitro antiproliferative effects against HCT116 cells, in either its free or emulsified form [58]. According to the authors, CUR-PIP was more effective, as compared to CUR and CUR emulsion, while PIP and PIP emulsion did not show inhibition. The CUR-PIP nanoemulsion ( $25 \mu \mathrm{M}-7 \mu \mathrm{M})$ inhibited cell proliferation by $50 \%$ via cell cycle arrest at the $\mathrm{G} 2 / \mathrm{M}$ phase and in- 
duced apoptosis. In addition, a CUR nanoemulsion exerted a four-fold increase in caspase- 3 , in contrast to a six-fold increase exerted by co-administered CUR-PIP. Curcumin is also commonly co-loaded in nanosystems with demethoxy CUR and bisdemethoxy CUR, both of them are related curcuminoids. A nanoemulsion obtained by sonication with Tween 80 and using a Curcuma longa extract (curcuminoid concentration $2000 \mu \mathrm{g} / \mathrm{mL}$, particle size $12.6 \mathrm{~nm}$, encapsulation efficiency $75 \%$, three months after encapsulation and stored at $4{ }^{\circ} \mathrm{C}$ ) has shown inhibitory effects on $\mathrm{A} 549$ ( $\left.\mathrm{IC}_{50} 3.9 \mu \mathrm{g} / \mathrm{mL}\right)$ and on H460 lung cancer $\left(\mathrm{IC}_{50} 2.9 \mu \mathrm{g} / \mathrm{mL}\right.$ ) cell lines, according to a cell cycle arrest at G2/M [59]. Morevore, the activities of caspase-3, caspase-8, and caspase- 9 had a dose-dependent increase in both cell lines in response to both treatments, which was accompanied by a dose-dependent increase in cytochrome $\mathrm{C}$ expression and a dose-dependent decrease in CDK1 expression.

Solid lipid nanoparticles (SLN). SLN were first developed ca. 1990 (with patents and papers published a few years after) [60] and are the first generation of lipid nanoparticles $(50-1000 \mathrm{~nm})$ [61]. They contain crystallized lipid droplets that are solid at room and body temperatures $[62,63]$, with the drug or the molecule of interest loaded into the solid lipid phase [64]. The advantages of SLN include high drug loading capacity, great stability, good biocompatibility, and improved pharmacokinetics. Their hydrophobicity makes them promising to achieve controlled release and targeted drug delivery to the mononuclear phagocyte system [65]. Effects on the stability of SLN have been reported during storage, mostly due to loss of the solid crystalline structure, which can cause the expulsion of the bioactive compound and, therefore, a rapid initial release [66].

Curcumin-loaded SLN were tested in vitro against MDA-MB231 cells, which revealed a significantly higher cytotoxicity, cellular uptake, and induced apoptosis, as compared to F-CUR [67]. Curcumin-based SLN have shown increased pharmacokinetics and anticancer activity when the molecule was co-loaded with resveratrol and gelucire and tested in vitro against human colon cancer HCT-116 cells [68].

Nanostructured lipid carriers (NLC). Nanostructured lipid carriers are the second generation of drug carriers. They are made up of surfactants and biocompatible lipids that are solid at ambient temperature, which allows them to immobilize drugs and prevent the polymerization of particles within their matrix. Nanostructured lipid carriers have increased drug-loading capacity, as compared to the first generation of lipid-based nanotransporters, due to their liquid-phase lipids [61]. The intestinal permeation of a CUR-loaded NLC has been studied in vitro in Caco-2 cells [69]. The formulation protected the com- pounds from degradation under basic $\mathrm{pH}$, significantly improved the solubility of CUR, and increased its apparent permeation coefficient. Another study reported a co-loaded CUR-lactoferrin NLC that was prepared as a potential delivery system to cancerous cells through both active and passive targeting [70]. For example, the lactoferrin vector was used for active targeting due to its ability to target tumor cells (mediated by receptors), while the enhanced effect of permeation and retention was considered for passive targeting. Results showed improved in vitro cellular uptake, targeting capability, and cytotoxicity against the human colon cancer cell line HCT116, which was related to early apoptosis after $24 \mathrm{~h}$ of incubation.

On the other hand, it has been reported that NLC have a higher loading capacity and greater stability than SLN. This is mainly attributed to the fact that NLC have an imperfect crystalline structure and due to the presence of liquid lipids it prevents the expulsion of the drug $[61,66]$.

Liposomes. Liposomes are one of the most well-studied nanosystems. They are self-assembled vesicles with at least one phospholipid bilayer with a diameter size in the range of 50-450 nm when used for medical purposes, and are often used to deliver both hydrophilic and hydrophobic molecules [71,72]. Their main advantages include high biocompatibility, safety, and flexibility (the latter can be modulated by the concentration of cholesterol in the lipid membrane) [40,73,74]. PEGylated long-circulating liposomes with co-encapsulated CUR-doxorubicin inhibited C26 (murine colon carcinoma) cell proliferation, in conjunction with inhibition of angiogenic/inflammatory proteins in an NF-kB-dependent manner [18].

Zhang et al. [75] reported that a combination of nanosized particles and the inclusion of glutathione (which has a thiol group that can initiate thiolysis and release CUR) results in a synergistic effect. This has been previously reported when using glutathione-responsive self-delivery nanocapsules (100 nm), a strategy that increases cellular uptake efficiency, intracellular CUR delivery, and transport to the nucleus, which results in growth inhibition of HeLa (human cervical carcinoma) cells [75]. Similar results have been obtained in glutathione-sensitive PEGylated CUR prodrug nanomicelles [76].

Polymeric nanoparticles (PNP). Polymeric nanoparticles are solid colloids with a size of up to $1000 \mathrm{~nm}$; the drug is loaded into the polymeric matrix, preferably using biodegradable polymers $[77,78]$. If the drug is distributed within a polymeric matrix (i.e., surrounded by the polymer) they are referred to as nanocapsules. Alternatively, if the drug is homogeneously dispersed in the polymeric matrix they are called nanospheres $[78,79]$. Their main advantages include their reactivity, surface 
area, stability, and high membrane permeability [80-82]. In particular, their stability tends to increase due to minimal exposure to ambient conditions (thereby delaying oxidation or degradation reactions), while their release may be regulated according to the use of different encapsulating materials [83]. Umerska et al. [84] reported that polymeric nanoparticles formulated with curcumin and an ethyl acrylate copolymer, methyl methacrylate (particle size $231 \pm 8 \mathrm{~nm}, \mathrm{EE} \% 61.7 \pm 4.7$, and $\mathrm{CE} \%$ $56.1 \pm 4.3 \mathrm{mg} / \mathrm{g}$ ) have the advantage of releasing curcumin in aqueous medium (PBS pH 7.4) almost immediately (91\% at $60 \mathrm{~min}$ ), which was associated with the ammonium groups present in the salts of the polymer material. Previous studies have reported that $90 \%$ of CUR at $\mathrm{pH} 7.4$ degrades in $30 \mathrm{~min}$ [85], so the system developed by Umerska et al. [84] would increase its residence time. Polymeric nanoparticles sensitive to $\mathrm{pH}$ exerted an antiangiogenic effect when assayed against human umbilical vein endothelial cells; particles co-delivered doxorubicin-CUR in an amphiphilic poly- $\beta$-amino ester copolymer. Their mechanism was apparently related to the VEGF pathway, according to the results of inhibited proliferation, migration, invasion, and tube formation [39]. It was observed that at $\mathrm{pH} 5.8$, more than $90 \%$ of CUR and doxorubicin were released, and this amount is significantly higher than that observed at $\mathrm{pH} 7.4$ (59.37\% and $66.63 \%$, respectively). This represents an advantage in the systems used to transport drugs to carcinogenic environments because in this type of formulation, it is preferred that the nanoparticle is stable at $\mathrm{pH} 7.4(\mathrm{pH}$ of a healthy tissue) and that CUR release is carried out in an acidic $\mathrm{pH}$, which is characteristic of tumor cell endosomes $(\mathrm{pH}$ 5.0-5.8) [39]. On the other hand, Bonaccorso et al. [85] compared CUR-loaded polymeric (PNP with PLGA) and lipid nanoparticles (SLN with hydrogenated coco-glycerides and poloxamer 188). They reported greater stability at 135 days ( $>90 \%$ retention), lower average particle size $(127.10 \pm 11.30 \mathrm{~nm})$, and higher EE\% (90.49 $\pm 1.20 \%)$ in CUR-SL, as compared to CURPNP $(338.20 \pm 12.25 \mathrm{~nm}, \mathrm{EE} \% 78.04 \pm 0.54>70 \%$ CUR $)$. This was associated with the compatibility of the compound with the lipid medium and the presence of the surfactant in the polymer formulation (which has been reported to affect the \% EE). In addition, they reported better cellular uptake of SLN, which was associated with smaller sizes and possible internalization by endocytosis (particles with sizes $<150 \mathrm{~nm}$ can be internalized by clathrin- or caveolin-mediated endocytosis), while particles with sizes from $250 \mathrm{~nm}$ to $3 \mu \mathrm{m}$ can be internalized by macropinocytosis and phagocytosis.

Lipid-polymer hybrid nanoparticles (LPHN). Lipid-polymer hybrid nanoparticles have recently emerged as a strategy directed to take advantage of the intrinsic benefits of both liposomes and PNP, as well as to improve drawbacks such as structural disintegration, limited circulation time, and drug leakage.
The hybrid materials are constituted by lipophilic and hydrophilic polymers which contribute to increase their systemic mobility and residence time [86]. The advantages of this hybrid system include high encapsulation efficiency, well-defined release kinetics, well-tolerated serum stability, and well-triggered tissue, cellular, and molecular targeting properties [40]. An LPHN was co-loaded with CUR and with docetaxel (82\% and $90 \%$ average EE, respectively) and assayed in mice bearing PC3 (human prostate cancer) tumor xenografts [87]. The results showed higher cytotoxicity and a synergistic effect, which resulted in tumor growth inhibition without any obvious side effects. Kumar et al. [86] reported CUR-loaded polymer/ lipid-based nanoparticles made with the emulsification-evaporation method. They report $53 \% \mathrm{EE}$, hemocompatibility in the range of $60-120 \mu \mathrm{g} / \mathrm{mL}$, and improved apoptotic activity in MCF-7 cells as compared to free CUR [86]. However, both authors only carried out release studies at $\mathrm{pH} 7.4$, so the question of the behavior of LPN at an acid $\mathrm{pH}$ remains.

Nanoemulsions. Nanoemulsions are composed of an oil phase in a continuous aqueous phase, with average diameters $<200 \mathrm{~nm}$ $[88,89]$. The oil and aqueous phases contact each other through a thin interfacial surfactant layer [90]. Some of their advantages include high surface area and high kinetic stability against various types of instabilities. Nanoemulsions have been commercially used to encapsulate CUR and other bioactive agents [91,92]. Their properties allow them to be potential carriers for hydrophobic compounds like CUR, since it can increase its solubility by 1400 -fold [90]. When CUR-loaded nanoemulsions were tested, results showed an antiangiogenic effect since there was inhibition of new vessel formation and reduced microvessel density in mice. Moreover, increased CUR solubility and stability and decreased tumor volume were also reported [25]. Table 1 lists the most relevant reports of CURloaded nanosystems, while Table 2 summarizes nanosystems in which CUR was co-loaded with another molecule, resulting in an improved chemotherapeutic effect.

Guerrero et al. [111] reported the anticancer effects of a CURloaded nanoemulsion in an in vivo and in vitro study. Evidence suggests no toxicity against control HEK-293T cells (human embryonic kidney cells), while significant toxicity against AGS, HT29, MDA-MB-231, and B16F10 cells (gastric, colon, breast, and melanoma cells, respectively) was observed when using doses up to $100 \mu \mathrm{M}$. In vivo (C57BL/6 mice) data showed that a topical application prevented regrowth and metastasis of excised tumors (melanoma), in contrast to a significant recurrence $(70 \%)$ in untreated animals. Based on their data, the authors propose that their CUR nanoemulsion can inhibit tumor growth and metastasis, with a particular focus on patients who have undergone surgery to have them excised. 
Inostroza et al. [112] report significant effectiveness of a CUR oil-in-water nanoemulsion against gastric cancer cells (AGS). CUR-based treatments were significantly effective antiproliferative agents in concentrations of $12.5-100 \mu \mathrm{M}$, while the empty system (without CUR) showed no effect or potential toxicity. Subsequent experiements incorporated the nanoemulsion into an alginate microgel, which the authors argue may be useful as controlled-release delivery mechanisms. This study

\begin{tabular}{|c|c|c|c|c|}
\hline System & $\begin{array}{l}\text { Model (in vitro, except } \\
\text { where indicated) }\end{array}$ & Size (nm), EE (\%) & Effects & Ref. \\
\hline \multirow[t]{3}{*}{ nanocrystals } & MCF-7 and A549 cells & $153.2 \pm 56.4$, N.A. & $\uparrow$ cellular uptake and cytotoxicity & [93] \\
\hline & $\begin{array}{l}\text { in vivo: rabbits and Wistar } \\
\text { rats }\end{array}$ & 74, N.A. & $\begin{array}{l}\downarrow \text { systemic toxicity; } \\
\uparrow \text { concentration in the lungs }\end{array}$ & {$[51]$} \\
\hline & HeLa cells & $100 \pm 20,12-14$ & $\begin{array}{l}\text { no cytotoxicity with } 500 \mu \mathrm{g} / \mathrm{mL} \text { of } \\
\text { CUR }\end{array}$ & {$[94]$} \\
\hline \multirow[t]{2}{*}{ SLN } & MCF-7 cells & $152.7 \pm 9.9,96.79 \pm 1.81$ & $\begin{array}{l}\text { sustained release; } \downarrow \text { cell growth; } \\
\uparrow \text { cellular uptake }\end{array}$ & {$[95]$} \\
\hline & A549 cells & $20-80,75$ & $\begin{array}{l}\uparrow \text { drug concentration in target } \\
\text { tissue; } \downarrow \text { xenograft growth }\end{array}$ & {$[96]$} \\
\hline \multirow[t]{3}{*}{ NLC } & U373MG cells & $146.8,90.86$ & $\begin{array}{l}\mathrm{IC}_{50} \text { of } 9.8 \mathrm{ng} / \mathrm{mL} ; \uparrow \text { cellular } \\
\text { uptake }\end{array}$ & {$[97]$} \\
\hline & MG-63 and KHOS cells & $98.2,50$ & $\uparrow$ circulation time; $\uparrow$ apoptosis & {$[98]$} \\
\hline & KHOS and MCF-7 cells & $98.2,50$ & $\uparrow$ effectiveness; $\downarrow \mathrm{IC}_{50}$ & {$[99]$} \\
\hline \multirow[t]{10}{*}{ liposomes } & A549 cells & $94.66 \pm 22.0$ N.A. & $\uparrow$ uptake efficiency & {$[100]$} \\
\hline & B16-F10 and L929 cells & $100 \pm 6.5,65.8 \pm 4.5$ & $\uparrow$ uptake efficiency & {$[101]$} \\
\hline & B16-F10 cells & $276.9 \pm 14.4,86.8 \pm 6.0$ & $\uparrow$ cellular inhibition & [102] \\
\hline & in vivo: Swiss albino mice & $140 \pm 60,72 \pm 5$ & $\begin{array}{l}\uparrow \text { cellular antioxidant enzymes; } \\
\text { mitigated mitochondrial } \\
\text { destruction and hepatotoxicity; } \\
\downarrow \text { oxidative damage }\end{array}$ & {$[103]$} \\
\hline & $\begin{array}{l}\text { m-MSCs; in vivo: } \\
\text { C57BL66J }\end{array}$ & $377.0 \pm 14.6$, N.A. & $\begin{array}{l}\uparrow \text { uptake efficiency; } \downarrow \text { lung } \\
\text { metastasis; } \downarrow \text { tumor growth }\end{array}$ & {$[104]$} \\
\hline & MDA-MB-231 cells & 110, N.A. & $\begin{array}{l}\downarrow \text { growth; } \uparrow \text { carcinogenic } \\
\text { effects }\end{array}$ & {$[105]$} \\
\hline & $\begin{array}{l}\text { in vivo: RG2 (rat glioma) } \\
\text { cells }\end{array}$ & $169 \pm 4.8,35 \pm 1.2$ & $\begin{array}{l}\uparrow \text { antitumoral effects; } \downarrow \text { tumor } \\
\text { size; } \uparrow \text { pharmacokinetics }\end{array}$ & {$[106]$} \\
\hline & $\begin{array}{l}\text { Colon-26 tumor-bearing } \\
\text { mice }\end{array}$ & $248 \pm 3.98,65.77 \pm 3.17$ & $\downarrow$ tumor volume; $\uparrow$ cytotoxicity & {$[107]$} \\
\hline & HT29 and HCT116 cells & 136,95 & $\uparrow$ uptake efficiency; $\uparrow$ apoptosis & {$[108]$} \\
\hline & B16 (melanoma) cells & $202.4 \pm 5.2,97.75 \pm 0.5$ & $\begin{array}{l}\uparrow \text { apoptotic efficiency; } \downarrow \text { tumor } \\
\text { growth }\end{array}$ & {$[109]$} \\
\hline \multirow[t]{2}{*}{ nanoemulsions } & HT29 cells & $12.7 \pm 0.1$, N.A. & $\begin{array}{l}\uparrow \text { apoptosis; } \downarrow \text { migration of } \\
\text { cancer cells }\end{array}$ & [110] \\
\hline & $\begin{array}{l}\text { non-cancerous human } \\
\text { cells (HEK-293T); AGS, } \\
\text { HT29, MDAMB-231, and } \\
\text { B16-F10 cells } \\
\text { in vivo: tumor growth and } \\
\text { lung metastasis }\end{array}$ & $200 \mathrm{~nm}, 95 \%$ & $\begin{array}{l}\text { cytotoxic on AGS, HT29, } \\
\text { MDA-MB-231, and B16F10 cells, } \\
\text { safe on HEK-293T cells } \\
\text { in vivo: prevents tumor regrowth } \\
\text { and spontaneous lung metastasis } \\
\text { CUR retention in rats increased } \\
\text { in nanoemulsions (15 d), as } \\
\text { compared to the compound } \\
\text { administered in DMSO ( } 4 \mathrm{~d})\end{array}$ & {$[111]$} \\
\hline $\begin{array}{l}\text { gold nanospheres or } \\
\text { nanorods and } \\
\text { nanoemulsions in } \\
\text { microgels }\end{array}$ & HEK293T & $\begin{array}{l}\text { nanospheres-microgels } \\
220 \mu \mathrm{m} \text { and } \\
\text { nanoemulsions-microgels } \\
540 \mu \mathrm{m}\end{array}$ & $\begin{array}{l}\text { preferential toxicity against } \\
\text { cancerous cells }\end{array}$ & {$[112]$} \\
\hline
\end{tabular}


Table 1: CUR-loaded nanosystems in which significant anticancer effects have been reported. (continued)

\begin{tabular}{|c|c|c|c|c|}
\hline \multirow[t]{3}{*}{ nanosuspensions } & $\begin{array}{l}\text { in vivo: hepatocarcinoma } \\
\text { mice }\end{array}$ & $186.33 \pm 2.73,67.07$ & $\begin{array}{l}\uparrow \text { antitumor efficacy; } \downarrow \text { tumor } \\
\text { growth and tumor size }\end{array}$ & [113] \\
\hline & PC-3 cells & $34.54 \pm 2.2$, N.A. & $\begin{array}{l}\uparrow \text { apoptosis; } \uparrow \text { anticancer } \\
\text { potential }\end{array}$ & [114] \\
\hline & SKOV3 cells & 180-222, N.A. & $\begin{array}{l}\downarrow \text { tumor growth; } \\
\uparrow \text { tumor-bearing mice life span }\end{array}$ & [115] \\
\hline
\end{tabular}

EE: encapsulation efficiency; N.A.: not available; SLN: solid lipid nanoparticles; NLC: nanostructured lipid carrier; MCF-7: human breast cancer cells; A549: human lung epithelial carcinoma cells; HeLa: human cervical carcinoma cells; U373MG: brain cancer astrocytoma-glioblastoma cells; MG-63: osteosarcoma cells; KHOS: osteosarcoma cells; B16-F10: murine melanoma cells; L929: murine fibroblast cells; m-MSCs: adipose-derived murine mesenchymal stem cells; C57BL66J: mice with pulmonary melanoma metastasis; MDAMB-231: human breast cancer cells; HT29: human colorectal adenocarcinoma cells; HCT116: human colon carcinoma cells; AGS: human gastric adenocarcinoma; PC-3: prostate cancer cells; SKOV3: human ovarian adenocarcinoma cells.

Table 2: CUR co-loaded nanosystems where significant anticancer effects have been reported.

\begin{tabular}{|c|c|c|c|c|c|}
\hline System & $\begin{array}{l}\text { Model (in vitro, } \\
\text { except where } \\
\text { indicated) }\end{array}$ & Size (nm), and EE (\%) & $\begin{array}{l}\text { Co-loaded } \\
\text { molecule }\end{array}$ & Effects & Ref. \\
\hline \multirow[t]{2}{*}{ nanococrystals } & $\begin{array}{l}\text { in vivo pancreatic } \\
\text { cancer }\end{array}$ & N.A., N.A. & pyrogallol & $\downarrow$ tumor size & {$[116]$} \\
\hline & U87MG cells & $28.79 \pm 0.86,99.2 \pm 2.6$ & "Coformer A" & $\begin{array}{l}\uparrow \text { pharmacokinetics; } \\
\uparrow \text { distribution in the brain }\end{array}$ & {$[117]$} \\
\hline \multirow[t]{2}{*}{ NLC } & $\begin{array}{l}\text { HCT116 and HT29 } \\
\text { cells }\end{array}$ & $340.6 \pm 33.64$, N.A. & ginsenoside & $\uparrow$ uptake efficiency & {$[118]$} \\
\hline & PC3 cells & $122 \pm 6,93 \pm 1$ & genistein & $\downarrow$ cell viability & {$[119]$} \\
\hline \multirow[t]{2}{*}{ PNP } & HT26 cells & $204.3 \pm 11.0,35.7 \pm 4.1$ & camptothecin & $\begin{array}{l}\uparrow \text { antitumoral effects; } \uparrow \text { uptake } \\
\text { efficiency }\end{array}$ & {$[120]$} \\
\hline & K562 cells & $248 \pm 1.6,8.6$ & doxorubicin & $\uparrow$ cytotoxicity & {$[121]$} \\
\hline nanosuspensions & $\begin{array}{l}\text { MCF-7 cells; in vivo } \\
\text { Swiss albino mice }\end{array}$ & $80 \pm 20$, N.A. & docetaxel & $\begin{array}{l}\uparrow \text { cytotoxicity; } \uparrow \text { uptake } \\
\text { efficiency; sensitization of tumor } \\
\text { cells; inhibition of } p \text {-glycoprotein }\end{array}$ & {$[122]$} \\
\hline \multirow[t]{2}{*}{ nanoemulsions } & $\begin{array}{l}\text { PC3 and DU145 } \\
\text { cells and murine } \\
\text { calvarial osteoblast }\end{array}$ & $137.1 \pm 44.6,98 \pm 2.3$ & etoposide & $\begin{array}{l}\uparrow \text { differentiation; } \uparrow \text { uptake } \\
\text { efficiency }\end{array}$ & {$[123]$} \\
\hline & SKOV3 cells & $144 \pm 1.5,97.4 \pm 0.3$ & paclitaxel & $\begin{array}{l}\downarrow \text { NF-kB activity; modulated } \\
\text { P-glycoprotein expression; } \\
\uparrow \text { cytotoxicity; } \uparrow \text { apoptosis }\end{array}$ & {$[124]$} \\
\hline
\end{tabular}

EE: encapsulation efficiency; N.A.: not available; NLC: nanostructured lipid carrier; PNP: polymeric nanoparticles; U87MG: human glioblastoma cells; HCT116: colon cancer cells; HT29: human colorectal adenocarcinoma cells; PC3: prostate cancer cells; HT26: colon cancer cells; K562: myelogenous leukemia cells; MCF-7: breast cancer cells; DU145: prostate cancer cells; SKOV3: human ovarian adenocarcinoma cells.

highlights the versatility of nanoemulsions since their performance can be fine-tuned with the aid of other systems, such as microgels.

\section{Nanosystems that respond to external stimuli}

In addition to their size and other advantages previously discussed, nanosystems can also be prepared such that they release their loaded compound upon receiving an internal and/or external stimulus in order to increase their versatility [12]. Figure 3 summarizes the key factors for the design of nano- systems for targeted cancer therapy. Curcumin-loaded nanosystems have been designed to respond to various external stimuli such as light [125], magnetic fields [126], ultrasound [127] and electric fields [128], or magnetic nanocarriers that respond to changes in $\mathrm{pH}$ by increasing the selectivity of the release site [129].

Magnetic nanoparticles (MNP). Magnetic nanoparticles contain molecules capable of responding to magnetic fields, which can be magnetically directed to the target tissue where 


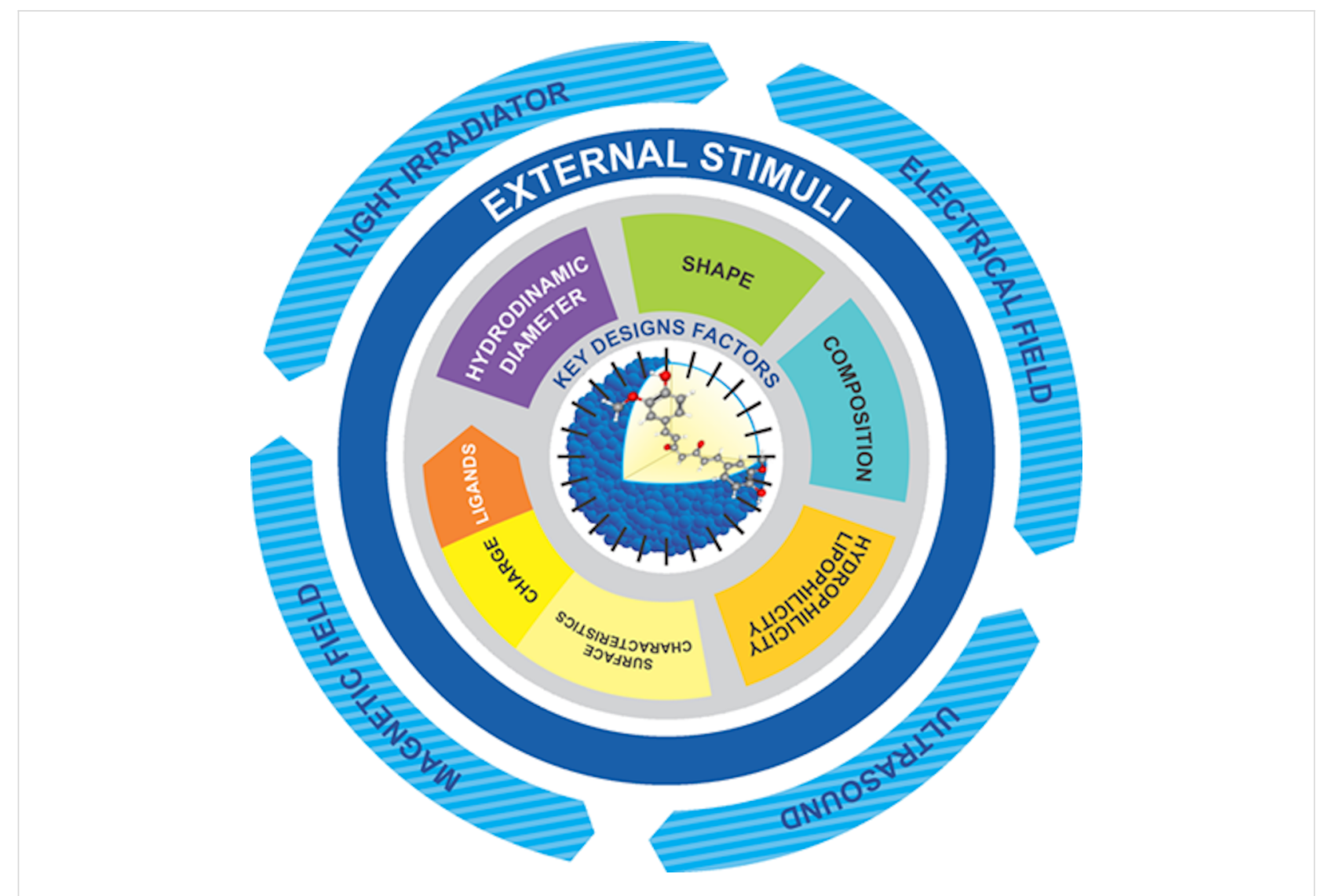

Figure 3: Key factors for the design of nanosystems for targeted cancer therapy.

the compound of interest can be released [130,131]. Magnetic nanoparticles can also improve imaging and cause localized hyperthermia $\left(39.5-43{ }^{\circ} \mathrm{C}\right)$, which can be used as a complementary attack strategy against cancer cells [126].

Curcumin-loaded MNP (94.2 $\mu \mathrm{g} / \mathrm{mg}$ of nanoparticles) were assayed against MDA-MB-231 cells. They contained iron oxide and $\beta$-cyclodextrin and were coated with Pluronic F68 polymer (polyethylene oxide-co-polypropylene oxide-co-polyethylene oxide) with an average size of $9 \mathrm{~nm}$. Results showed that cells readily internalized MNP by endocytosis, which simultaneously allowed for imaging the affected cells [132]. Other report showed that, using the same breast cancer cells, alginate/ chitosan MNP had a 3-6-fold increase in cellular uptake, as compared to F-CUR [133]. This has been shown to increase the antiproliferative effect ( $\mathrm{IC}_{50} 12.4 \mu \mathrm{M}$ ) of CUR, as compared to the free molecule $\left(\mathrm{IC}_{50} 17.2 \mu \mathrm{M}\right)$ within the assayed range $(5-40 \mu \mathrm{M})$ [132].

Cui et al. [134] reported the use of CUR-loaded MNP to achieve active targeting in conjunction with transferrin receptor binding peptide $\mathrm{T} 7$, which yielded a dual targeting structure that was able to cross the blood-brain barrier, a significant obstacle when treating brain tumors. Similarly, an improved internalization of CUR-loaded MNP was also observed in HPAF-II and Panc-1 human pancreatic cancer cell lines (54.06\% and 53.86\%, respectively), where a reduced cell proliferation was consequently obtained [135]. In another study, CUR-loaded MNP were significantly more effective in reducing tumor size $(71.2 \%)$ in xenotransplanted mice (HPAF-II pancreatic cancer cells), as compared to F-CUR (35.9\%). This suggests the need to take into account more studies performed on human subjects. Data generated in vitro and in animals should complement the efficacy of a treatment and can be used to determine its mechanisms of action at cellular and molecular scales. However, there is no substitute for human-derived data. Figure 1 summarizes relevant data generated on clinical trials.

Curcumin-loaded MNP had a significantly improved pharmacokinetics in serum $(1792.19 \pm 644 \mathrm{ng} / \mathrm{mL})$ compared to CUR (766.54 $\pm 256 \mathrm{ng} / \mathrm{mL}$ ) [135]. Furthermore, when particles were administered intratumorally $(10.5 \pm 0.54 \mathrm{~nm})$, nanosystems were detected $(\mathrm{mg} \mathrm{Fe} / \mathrm{g}$ of tissue) in the tumor $(1.04)>$ liver $(0.39)>$ brain $(0.14)>$ spleen $(0.06)$. When administered intraperitoneally, they were detected in the tumor (0.48) and spleen $(0.78)$ [135]. The distribution in other organs may be as- 
sociated with reduced particle size, improvements in permeability, and tissue retention.

Curcumin-loaded superparamagnetic iron oxide nanoparticles functionalized with sodium dodecyl sulfate (SDS) and coated with chitosan (40-45 nm), were able to induce apoptosis (IC 50 $30 \mu \mathrm{g} / \mathrm{mL}$ ) in HeLa (cervical cancer) cells by damaging the DNA and increasing caspase-3 [136]. Curcumin-loaded, pH-sensitive Janus magnetic mesoporous silica nanoparticles showed a synergistic therapeutic effect in in vivo and in vitro models of liver cancer due to their superior superparamagnetic properties, hyperthermia, high CUR-loading capacity, and sensitivity to the microenvironment of the tumor [137]. Authors argue that the magnetic sensitivity of nanosystems, precise drug delivery, and sustained release support their recommendation to be used as a drug delivery mechanism to induce apoptosis due to hyperthermia $\left(41.85{ }^{\circ} \mathrm{C}\right)$ [136] and higher drug concentration at the target site [138].

Photodynamic nanosystems. Photodynamic therapy is based on using light to stimulate photosensitive molecules, which absorb the energy of the photons and interact with oxygen, subsequently producing reactive species that promote cytotoxicity, immunostimulation, and/or regulate tumor vascularity [139]. Previous research has reported the potential use of CUR in an anticancer photodynamic therapy [140,141], in which this combined approach induces mitochondria-dependent apoptosis (70\% of cell viability inhibition) in a human head and neck cancer cell line (AMC-HN3), as compared to individually using F-CUR ( $10 \%$ inhibition) or phototherapy ( $50 \%$ inhibition). The apoptosis-promoting effect of the phototherapy-CUR combination is the result of increased nuclear fragmentation, nuclear condensation and reactive oxygen species (ROS) generation, loss of mitochondrial membrane potential, increased cytosolic levels of cytochrome $\mathrm{C}$, and regulation of apoptosis-related proteins (caspase-9, caspase-3, and PARP) [139].

Nitric oxide has been reported to promote resistance to photodynamic therapy in cancer cells, possibly due to its vasodilation effects. It activates MMP-9 and downregulates TIMP-1, allowing CUR to contribute to reduce the resistance to photodynamic therapy by inhibiting nitric oxide in cancer cells [14] Dev et al. [142] reported that CUR-loaded BSA nanoparticles (6 $\mu \mathrm{M})$ exposed to blue LED light inhibited the growth of glioblastoma stem cells better than F-CUR, which was attributed to an improved sustained intracellular release of CUR. Curcumin-loaded PLGA [poly(lactic-co-glycolic acid)] nanoparticles (hydrodynamic diameter of $200 \mathrm{~nm}$ ) were induced with LEDs, and showed higher photocytotoxicity against SKOV3 human ovarian adenocarcinoma cells as compared to F-CUR. This was associated with an improvement in cellular internalization of the nanosystem and its greater potential to produce ROS [143]. A similar behavior was observed in cervical carcinoma cell lines treated with nanoemulsion-photostimulated CUR, where cell viability was reduced to $<5 \%$ and an increase in caspase- 3 and caspase- 7 activity was apparent [144].

Inostroza et al. [112] reported the promising application of gold nanostructures with CUR-loaded alginate microgels, which showed photothermal properties. High CUR retention and preferential toxicity against cancerous cells was also shown.

The photoactive agent, wavelength, time of exposure, and distance to the light source are important factors that determine the effectiveness of phototherapy against cancer cells [142]. For example, Rahimi-Moghaddam et al. [140] reported a higher cytotoxic effect of a gold-CUR nanosystem used as photothermal therapy against breast cancer cells when exposed to an $808 \mathrm{~nm}$ laser $\left(1.5 \mathrm{~W} / \mathrm{cm}^{2}\right)$, as compared to a $650 \mathrm{~nm}$ laser $\left(1.5 \mathrm{~W} / \mathrm{cm}^{2}\right)$.

The advantages of incorporating CUR into nanostructures used as photodynamic anticancer therapy are diverse. They include making nasal delivery a possibility, thereby minimizing patient discomfort [145], subcellular internalization of the molecule (enhancing sensitization and damage to cancer cells), as well as controlled and constant dosing. Therefore, CUR-loaded nanosystems used as photosensitive therapeutic agents could be an alternative to treat some forms of cancer where similar therapies are already in use (such as cutaneous T-cell lymphoma, basal skin cancer, and esophageal cancer) and to reduce drug resistance. However, further research is necessary to validate its possible beneficial effects in humans. It should also be emphasized that there is significant variation in the metabolism and rate of nanosystems in experimental animals as compared to humans. For example, the type of bond between CUR and the polymeric material is a key factor since it is easier for mice, but not for humans, to break an ester bond than an amide bond [4]. Therefore, the physiological differences between animal models and humans must be considered when studying the effectiveness of nanosystems.

According to previous evidence, the use of nanosystems is highly flexible since it can be tailored for numerous applications with highly specific goals. Polymeric micelles and theranostics (a strategy that combines treatment and diagnostics) are two examples of such applications that are based on customizing the basic nanosystem. Although these are beyond the scope of the present work, their presence should be acknowledged as additional tools, which can be used to potentiate the already high bioactivity of CUR (and other molecules of 
interest) for anticancer or other health-promoting uses. It is also noteworthy, and a cautionary comment, that CUR has been considered as a candidate molecule for pan-assay interference compounds (PAINS) and invalid metabolic panaceas (IMPS), that is, a compound that interferes with most assay readouts and which appears to exhibit numerous bioactivities [146]. Thus, in vivo experimentation is required to conclusively validate the bulk of in vitro data reported in the literature.

\section{Conclusion}

Curcumin is a bioactive compound whose anticancer effects can be enhanced if administered within a nanosystem. According to independent experimental evidence, a successful formulation must have an optimized particle size and morphology. It can be incorporated into various types of nano-formulations, resulting in increased activity. Co-loading it with other compounds can lead to a synergistic effect or to minimized discrepancies in dosing, since both molecules will be simultaneously delivered. The main data and most conclusive information must be supported by in vivo models (and with human participants in particular), since CUR has been considered a candidate as a PAINS and IMPS compound. Thus, studies and data interpretation must be done with this in mind. Subsequent work in the area must consider the need to prioritize in vivo over in vitro experimentation, although the latter cannot be ruled out since it is an invaluable tool that allows researchers to elucidate mechanisms and mode of action of CUR in nanosystems.

\section{Acknowledgements}

The authors thank FEES-CONARE (115-B9-670), the National Laboratory of Nanotechnology (LANOTEC), the University of Costa Rica (UCR), the National Technical University (UTN), and the Center for Food Research and Development (CIAD).

\section{Funding}

This work was supported by Instituto de Bebidas de la Industria Mexicana de CocaCola through the project "Inducción de saciedad y modulación de la digestión intestinal de lípidos ejercidos por los compuestos fenólicos de aguacate Hass" (Premio Nacional en Ciencia y Tecnología de Alimentos 2019) and by CIAD-CONACYT. Authors also thank CONACYT for the Postdoctoral Fellowship awarded to NJSL. ADA is thankful to CIAD and CONACYT for their financial support.

\section{ORCID ${ }^{\circledR}$ iDs}

Andrea M. Araya-Sibaja - https://orcid.org/0000-0001-9809-6079 Norma J. Salazar-López - https://orcid.org/0000-0002-8597-3455 Krissia Wilhelm Romero - https://orcid.org/0000-0003-3763-1626 José R. Vega-Baudrit - https://orcid.org/0000-0002-2002-1744 J. Abraham Domínguez-Avila - https://orcid.org/0000-0001-6220-1623 Gustavo A. González-Aguilar - https://orcid.org/0000-0002-7452-286X

\section{References}

1. IARC. Globalcan, International Agency for Research on Cancer; 2018. https://gco.iarc.fr/today/home.

2. World Health Organization. Health statistics and information systems Disease burden and mortality estimates. https://www.who.int/healthinfo/global_burden_disease/estimates/en/in dex1.html.

3. Chen, W.-H.; Luo, G.-F.; Zhang, X.-Z. Adv. Mater. (Weinheim, Ger.) 2019, 31, 1802725. doi:10.1002/adma.201802725

4. Maeda, H.; Bharate, G. Y.; Daruwalla, J. Eur. J. Pharm. Biopharm. 2009, 71, 409-419. doi:10.1016/j.ejpb.2008.11.010

5. Bayón-Cordero, L.; Alkorta, I.; Arana, L. Nanomaterials 2019, 9, 474. doi:10.3390/nano9030474

6. Din, F. u.; Aman, W.; Ullah, I.; Qureshi, O. S.; Mustapha, O.; Shafique, S.; Zeb, A. Int. J. Nanomed. 2017, 12, 7291-7309. doi:10.2147/ijn.s146315

7. Moon, J. H.; Moxley, J. W., Jr.; Zhang, P.; Cui, H. Future Med. Chem. 2015, 7, 1503-1510. doi:10.4155/fmc.15.82

8. Mei, L.; Zhang, Z.; Zhao, L.; Huang, L.; Yang, X.-L.; Tang, J.; Feng, S.-S. Adv. Drug Delivery Rev. 2013, 65, 880-890. doi:10.1016/j.addr.2012.11.005

9. Tinkle, S.; McNeil, S. E.; Mühlebach, S.; Bawa, R.; Borchard, G.; Barenholz, Y. C.; Tamarkin, L.; Desai, N. Ann. N. Y. Acad. Sci. 2014, 1313, 35-56. doi:10.1111/nyas.12403

10. Soares, S.; Sousa, J.; Pais, A.; Vitorino, C. Front. Chem. (Lausanne, Switz.) 2018, 6, 360. doi:10.3389/fchem.2018.00360

11. Naziris, N.; Pippa, N.; Pispas, S.; Demetzos, C. Curr. Nanomed. 2016, 6, 166-185. doi:10.2174/2468187306666160712232449

12. Kang, H.; Hu, S.; Cho, M. H.; Hong, S. H.; Choi, Y.; Choi, H. S. Nano Today 2018, 23, 59-72. doi:10.1016/j.nantod.2018.11.001

13. Vareed, S. K.; Kakarala, M.; Ruffin, M. T.; Crowell, J. A.; Normolle, D. P.; Djuric, Z.; Brenner, D. E. Cancer Epidemiol., Biomarkers Prev. 2008, 17, 1411-1417. doi:10.1158/1055-9965.epi-07-2693

14. Şueki, F.; Ruhi, M. K.; Gülsoy, M. Photodiagn. Photodyn. Ther. 2019, 27, 95-99. doi:10.1016/j.pdpdt.2019.05.012

15. Kunnumakkara, A. B.; Bordoloi, D.; Harsha, C.; Banik, K.; Gupta, S. C.; Aggarwal, B. B. Clin. Sci. 2017, 131, 1781-1799. doi:10.1042/cs20160935

16. Duvoix, A.; Blasius, R.; Delhalle, S.; Schnekenburger, M.; Morceau, F.; Henry, E.; Dicato, M.; Diederich, M. Cancer Lett. 2005, 223, 181-190. doi:10.1016/j.canlet.2004.09.041

17. Dhivya, R.; Ranjani, J.; Bowen, P. K.; Rajendhran, J.; Mayandi, J.; Annaraj, J. Mater. Sci. Eng., C 2017, 80, 59-68. doi:10.1016/j.msec.2017.05.128

18. Sesarman, A.; Tefas, L.; Sylvester, B.; Licarete, E.; Rauca, V.; Luput, L.; Patras, L.; Banciu, M.; Porfire, A. Pharmacol. Rep. 2018, 70, 331-339. doi:10.1016/j.pharep.2017.10.004

19. Allegra, A.; Innao, V.; Russo, S.; Gerace, D.; Alonci, A.; Musolino, C. Cancer Invest. 2017, 35, 1-22. doi:10.1080/07357907.2016.1247166

20. Zhang, L.; Man, S.; Qiu, H.; Liu, Z.; Zhang, M.; Ma, L.; Gao, W. Environ. Toxicol. Pharmacol. 2016, 48, 31-38. doi:10.1016/j.etap.2016.09.021

21. Sneharani, A. H. J. Food Biochem. 2019, 43, e12909. doi:10.1111/jfbc.12909

22. Naksuriya, O.; Okonogi, S.; Schiffelers, R. M.; Hennink, W. E. Biomaterials 2014, 35, 3365-3383. doi:10.1016/j.biomaterials.2013.12.090 
23. Tomeh, M. A.; Hadianamrei, R.; Zhao, X. Int. J. Mol. Sci. 2019, 20, 1033. doi:10.3390/ijms20051033

24. Wang, M.; Jiang, S.; Zhou, L.; Yu, F.; Ding, H.; Li, P.; Zhou, M.; Wang, K. Int. J. Biol. Sci. 2019, 15, 1200-1214. doi:10.7150/ijbs.33710

25. Xiao, Y.; Xu, C.; Xiong, H.; Du, S.; Zhou, J.; Yin, L.; Yao, J. Eur. J. Pharm. Sci. 2018, 119, 121-134. doi:10.1016/j.ejps.2018.04.011

26. Gaikwad, D.; Shewale, R.; Patil, V.; Mali, D.; Gaikwad, U.; Jadhav, N. Int. J. Biol. Macromol. 2017, 104, 656-664. doi:10.1016/j.ijbiomac.2017.05.170

27. Mandracchia, D.; Tripodo, G.; Trapani, A.; Ruggieri, S.; Annese, T.; Chlapanidas, T.; Trapani, G.; Ribatti, D. Eur. J. Pharm. Sci. 2016, 93, 141-146. doi:10.1016/j.ejps.2016.08.027

28. Cheng, A.-L.; Hsu, C.-H.; Lin, J.-K.; Hsu, M. M.; Ho, Y.-F.; Shen, T.-S.; Ko, J.-Y.; Lin, J.-T.; Lin, B.-R.; Wu, M.-S.; Yu, H.-S.; Jee, S.-H. Anticancer Res. 2001, 21, 2895-2900.

29. Saghatelyan, T.; Tananyan, A.; Janoyan, N.; Tadevosyan, A.; Petrosyan, H.; Hovhannisyan, A.; Hayrapetyan, L.; Arustamyan, M.; Arnhold, J.; Rotmann, A.-R.; Hovhannisyan, A.; Panossian, A. Phytomedicine 2020, 70, 153218. doi:10.1016/j.phymed.2020.153218

30. Bayet-Robert, M.; Kwiatowski, F.; Leheurteur, M.; Gachon, F.; Planchat, E.; Abrial, C.; Mouret-Reynier, M.-A.; Durando, X.; Barthomeuf, C.; Chollet, P. Cancer Biol. Ther. 2010, 9, 8-14. doi:10.4161/cbt.9.1.10392

31. Garcea, G.; Berry, D. P.; Jones, D. J. L.; Singh, R.; Dennison, A. R.; Farmer, P. B.; Sharma, R. A.; Steward, W. P.; Gescher, A. J. Cancer Epidemiol., Biomarkers Prev. 2005, 14, 120-125.

32. Carroll, R. E.; Benya, R. V.; Turgeon, D. K.; Vareed, S.; Neuman, M.; Rodriguez, L.; Kakarala, M.; Carpenter, P. M.; McLaren, C.; Meyskens, F. L., Jr.; Brenner, D. E. Cancer Prev. Res. 2011, 4, 354-364. doi:10.1158/1940-6207.capr-10-0098

33. Sharma, R. A.; Euden, S. A.; Platton, S. L.; Cooke, D. N.; Shafayat, A.; Hewitt, H. R.; Marczylo, T. H.; Morgan, B.; Hemingway, D.; Plummer, S. M.; Pirmohamed, M.; Gescher, A. J.; Steward, W. P. Clin. Cancer Res. 2004, 10, 6847-6854. doi:10.1158/1078-0432.ccr-04-0744

34. Dhillon, N.; Aggarwal, B. B.; Newman, R. A.; Wolff, R. A.; Kunnumakkara, A. B.; Abbruzzese, J. L.; Ng, C. S.; Badmaev, V.; Kurzrock, R. Clin. Cancer Res. 2008, 14, 4491-4499. doi:10.1158/1078-0432.ccr-08-0024

35. Ide, H.; Tokiwa, S.; Sakamaki, K.; Nishio, K.; Isotani, S.; Muto, S.; Hama, T.; Masuda, H.; Horie, S. Prostate 2010, 70, 1127-1133. doi:10.1002/pros.21147

36. Zou, J. Y.; Su, C. H.; Luo, H. H.; Lei, Y. Y.; Zeng, B.; Zhu, H. S.; Chen, Z. G. J. Cell. Biochem. 2018, 119, 1420-1428. doi:10.1002/jcb.26302

37. Vadhan-Raj, S.; Weber, D. M.; Wang, M.; Giralt, S. A.; Thomas, S. K.; Alexanian, R.; Zhou, X.; Patel, P.; Bueso-Ramos, C. E.; Newman, R. A.; Aggarwal, B. B. Blood 2007, 110, 1177. doi:10.1182/blood.v110.11.1177.1177

38. Golombick, T.; Diamond, T. H.; Manoharan, A.; Ramakrishna, R. Am. J. Hematol. 2012, 87, 455-460. doi:10.1002/ajh.23159

39. Zhang, J.; Li, J.; Shi, Z.; Yang, Y.; Xie, X.; Lee, S. M.; Wang, Y.; Leong, K. W.; Chen, M. Acta Biomater. 2017, 58, 349-364. doi:10.1016/j.actbio.2017.04.029

40. Mukherjee, A.; Waters, A. K.; Kalyan, P.; Achrol, A. S.; Kesari, S.; Yenugonda, V. M. Int. J. Nanomed. 2019, 14, 1937-1952. doi:10.2147/ijn.s198353
41. Bi, C.; Miao, X. Q.; Chow, S. F.; Wu, W. J.; Yan, R.; Liao, Y. H.; Chow, A. H.-L.; Zheng, Y. Nanomedicine (N. Y., NY, U. S.) 2017, 13, 943-953. doi:10.1016/j.nano.2016.11.004

42. Pawar, S. S.; Dahifale, B. R.; Nagargoje, S. P.; Shendge, R. S. Nanosci. Nanotechnol. Res. 2017, 4, 59-66.

43. Gelperina, S.; Kisich, K.; Iseman, M. D.; Heifets, L. Am. J. Respir. Crit. Care Med. 2005, 172, 1487-1490. doi:10.1164/rccm.200504-613pp

44. Ma, Z.; Wang, N.; He, H.; Tang, X. J. Controlled Release 2019, 316, 359-380. doi:10.1016/j.jconrel.2019.10.053

45. Junyaprasert, V. B.; Morakul, B. Asian J. Pharm. Sci. 2015, 10, 13-23. doi:10.1016/j.ajps.2014.08.005

46. Gao, L.; Zhang, D.; Chen, M. J. Nanopart. Res. 2008, 10, 845-862. doi:10.1007/s11051-008-9357-4

47. Peltonen, L.; Hirvonen, J.; Laaksonen, T. Drug Nanocrystals and Nanosuspensions in Medicine. In Handbook of Nanobiomedical Research; Torchilin, V., Ed.; Frontiers in Nanobiomedical Research, Vol. 3; World Scientific, 2014; pp 169-197. doi:10.1142/9789814520652_0005

48. Rabinow, B. E. Nat. Rev. Drug Discovery 2004, 3, 785-796. doi:10.1038/nrd1494

49. Xie, M.; Fan, D.; Zhao, Z.; Li, Z.; Li, G.; Chen, Y.; He, X.; Chen, A.; Li, J.; Lin, X.; Zhi, M.; Li, Y.; Lan, P. Int. J. Pharm. 2015, 496, 732-740. doi:10.1016/j.jpharm.2015.11.016

50. Khan, M.; Akhtar, N.; Sharma, V.; Pathak, K. Pharmaceutics 2015, 7 , 43-63. doi:10.3390/pharmaceutics7020043

51. Hu, L.; Kong, D.; Hu, Q.; Gao, N.; Pang, S. Nanoscale Res. Lett. 2015, 10, 381. doi:10.1186/s11671-015-1085-y

52. Lao, C. D.; Ruffin, M. T., IV; Normolle, D.; Heath, D. D.; Murray, S. I.; Bailey, J. M.; Boggs, M. E.; Crowell, J.; Rock, C. L.; Brenner, D. E. BMC Complementary Altern. Med. 2006, 6, 10. doi:10.1186/1472-6882-6-10

53. Gigliobianco, M. R.; Casadidio, C.; Censi, R.; Di Martino, P. Pharmaceutics 2018, 10, 134. doi:10.3390/pharmaceutics 10030134

54. Spitzer, D.; Risse, B.; Schnell, F.; Pichot, V.; Klaumünzer, M.; Schaefer, M. R. Sci. Rep. 2015, 4, 6575. doi:10.1038/srep06575

55. Araya-Sibaja, A. M.; Fandaruff, C.; Wilhelm, K.; Vega-Baudrit, J. R.; Guillén-Girón, T.; Navarro-Hoyos, M. Mini-Rev. Org. Chem. 2020, 17, 518-538. doi:10.2174/1570193x16666190430153231

56. Ji, P.; Wang, L.; Chen, Y.; Wang, S.; Wu, Z.; Qi, X. Biomater. Sci. 2020, 8, 462-472. doi:10.1039/c9bm01605h

57. Ribas, M. M.; Aguiar, G. P. S.; Muller, L. G.; Siebel, A. M.; Lanza, M.; Oliveira, J. V. Ind. Crops Prod. 2019, 139, 111537. doi:10.1016/j.indcrop.2019.111537

58. Bolat, Z. B.; Islek, Z.; Demir, B. N.; Yilmaz, E. N.; Sahin, F.; Ucisik, M. H. Front. Bioeng. Biotechnol. 2020, 8, 50. doi:10.3389/fbioe.2020.00050

59. Chang, H.-B.; Chen, B.-H. Int. J. Nanomed. 2015, 10, 5059-5080. doi:10.2147/ijn.s87225

60. Muller, R. H.; Shegokar, R.; Keck, C. M. Curr. Drug Discovery Technol. 2011, 8, 207-227. doi:10.2174/157016311796799062

61. Iqbal, M. A.; Md, S.; Sahni, J. K.; Baboota, S.; Dang, S.; Ali, J. J. Drug Targeting 2012, 20, 813-830. doi:10.3109/1061186x.2012.716845

62. Müller, R. H.; Radtke, M.; Wissing, S. A. Int. J. Pharm. 2002, 242, 121-128. doi:10.1016/s0378-5173(02)00180-1

63. Katouzian, I.; Faridi Esfanjani, A.; Jafari, S. M.; Akhavan, S. Trends Food Sci. Technol. 2017, 68, 14-25. doi:10.1016/j.tifs.2017.07.017 
64. Weiss, J.; Decker, E. A.; McClements, D. J.; Kristbergsson, K.; Helgason, T.; Awad, T. Food Biophys. 2008, 3, 146-154. doi:10.1007/s11483-008-9065-8

65. Chen, W.-I.; Yuan, Z.-Q.; Liu, Y.; Yang, S.-d.; Zhang, C.-g.; Li, J.-Z.; Zhu, W.-j.; Li, F.; Zhou, X.-f.; Lin, Y.-m.; Zhang, X.-n. Int. J. Nanomed. 2016, 11, 325-336. doi:10.2147/ijn.s95540

66. Ghasemiyeh, P.; Mohammadi-Samani, S. Res. Pharm. Sci. 2018, 13, 288-303. doi:10.4103/1735-5362.235156

67. Rompicharla, S. V. K.; Bhatt, H.; Shah, A.; Komanduri, N.; Vijayasarathy, D.; Ghosh, B.; Biswas, S. Chem. Phys. Lipids 2017, 208, 10-18. doi:10.1016/j.chemphyslip.2017.08.009

68. Gumireddy, A.; Christman, R.; Kumari, D.; Tiwari, A.; North, E. J.; Chauhan, H. AAPS PharmSciTech 2019, 20, 145. doi:10.1208/s12249-019-1349-4

69. Chanburee, S.; Tiyaboonchai, W. J. Biomed. Mater. Res., Part B 2018, 106, 734-741. doi:10.1002/jbm.b.33884

70. Chaharband, F.; Kamalinia, G.; Atyabi, F.; Mortazavi, S. A.; Mirzaie, Z. H.; Dinarvand, R. Artif. Cells, Nanomed., Biotechnol. 2018, 46, 626-636. doi:10.1080/21691401.2017.1337020

71. Bozzuto, G.; Molinari, A. Int. J. Nanomed. 2015, 10, 975-999. doi:10.2147/ijn.s68861

72. Akhavan, S.; Assadpour, E.; Katouzian, I.; Jafari, S. M. Trends Food Sci. Technol. 2018, 74, 132-146. doi:10.1016/j.tifs.2018.02.001

73. Akbarzadeh, A.; Rezaei-Sadabady, R.; Davaran, S.; Joo, S. W.; Zarghami, N.; Hanifehpour, Y.; Samiei, M.; Kouhi, M.; Nejati-Koshki, K. Nanoscale Res. Lett. 2013, 8, 102. doi:10.1186/1556-276x-8-102

74. Shaheen, S. M.; Ahmed, F. R. S.; Hossen, M. N.; Ahmed, M.; Amran, M. S.; Anwar-UL-Islam, M. Pak. J. Biol. Sci. 2006, 9, 1181-1191. doi:10.3923/pjbs.2006.1181.1191

75. Zhang, H.; Zhang, Y.; Chen, Y.; Zhang, Y.; Wang, Y.; Zhang, Y.; Song, L.; Jiang, B.; Su, G.; Li, Y.; Hou, Z. Int. J. Pharm. 2018, 549, 230-238. doi:10.1016/j.ijpharm.2018.07.061

76. Zhang, H.-Y.; Sun, C.-y.; Adu-Frimpong, M.; Yu, J.-n.; Xu, X.-m. Int. J. Pharm. 2019, 555, 270-279. doi:10.1016/j.ijpharm.2018.11.049

77. Bolhassani, A.; Javanzad, S.; Saleh, T.; Hashemi, M.; Aghasadeghi, M. R.; Sadat, S. M. Hum. Vaccines Immunother. 2014, 10, 321-332. doi:10.4161/hv.26796

78. Hanemann, T.; Szabó, D. V. Materials 2010, 3, 3468-3517. doi:10.3390/ma3063468

79. Mohanraj, V. J.; Chen, Y. Trop. J. Pharm. Res. 2007, 5, 561-573. doi:10.4314/tjpr.v5i1.14634

80. Mallakpour, S.; Behranvand, V. eXPRESS Polym. Lett. 2016, 10, 895-913. doi:10.3144/expresspolymlett.2016.84

81. Galindo-Rodriguez, S. A.; Allemann, E.; Fessi, H.; Doelker, E. Crit. Rev. Ther. Drug Carrier Syst. 2005, 22, 419-464. doi:10.1615/critrevtherdrugcarriersyst.v22.i5.10

82. Pridgen, E. M.; Alexis, F.; Farokhzad, O. C. Expert Opin. Drug Delivery 2015, 12, 1459-1473. doi:10.1517/17425247.2015.1018175

83. Meng, R.; Wu, Z.; Xie, Q.-T.; Cheng, J.-S.; Zhang, B. Food Chem. 2021, 340, 127893. doi:10.1016/j.foodchem.2020.127893

84. Umerska, A.; Gaucher, C.; Oyarzun-Ampuero, F.; Fries-Raeth, I.; Colin, F.; Villamizar-Sarmiento, M. G.; Maincent, P.; Sapin-Minet, A. Antioxidants 2018, 7, 46. doi:10.3390/antiox7040046

85. Bonaccorso, A.; Pellitteri, R.; Ruozi, B.; Puglia, C.; Santonocito, D.; Pignatello, R.; Musumeci, T. Nanomaterials 2021, 11, 159. doi:10.3390/nano11010159
86. Kumar, S. S. D.; Mahesh, A.; Mahadevan, S.; Mandal, A. B. Biochim. Biophys. Acta, Gen. Subj. 2014, 1840, 1913-1922. doi:10.1016/j.bbagen.2014.01.016

87. Yan, J.; Wang, Y.; Zhang, X.; Liu, S.; Tian, C.; Wang, H. Drug Delivery 2016, 23, 1757-1762. doi:10.3109/10717544.2015.1069423

88. Assadpour, E.; Maghsoudlou, Y.; Jafari, S.-M.; Ghorbani, M.; Aalami, M. Int. J. Biol. Macromol. 2016, 86, 197-207. doi:10.1016/j.ijbiomac.2016.01.064

89. Mehrnia, M.-A.; Jafari, S.-M.; Makhmal-Zadeh, B. S.; Maghsoudlou, Y. Int. J. Biol. Macromol. 2016, 84, 261-267. doi:10.1016/j.ijbiomac.2015.12.029

90. Li, J.; Hwang, I.-C.; Chen, X.; Park, H. J. Food Hydrocolloids 2016, 60, 138-147. doi:10.1016/j.foodhyd.2016.03.016

91. Saxena, V.; Hasan, A.; Sharma, S.; Pandey, L. M. Int. J. Polym. Mater. Polym. Biomater. 2018, 67, 410-419. doi:10.1080/00914037.2017.1332625

92. Salvia-Trujillo, L.; Soliva-Fortuny, R.; Rojas-Graü, M. A.; McClements, D. J.; Martín-Belloso, O. Annu. Rev. Food Sci. Technol. 2017, 8, 439-466. doi:10.1146/annurev-food-030216-025908

93. Choi, J.-S. Int. J. Biol. Macromol. 2016, 92, 850-859. doi:10.1016/j.jibiomac.2016.07.101

94. Das, R. K.; Kasoju, N.; Bora, U. Nanomedicine (N. Y., NY, U. S.) 2010, 6, 153-160. doi:10.1016/j.nano.2009.05.009

95. Sun, J.; Bi, C.; Chan, H. M.; Sun, S.; Zhang, Q.; Zheng, Y. Colloids Surf., B 2013, 111, 367-375. doi:10.1016/j.colsurfb.2013.06.032

96. Wang, P.; Zhang, L.; Peng, H.; Li, Y.; Xiong, J.; Xu, Z. Mater. Sci. Eng., C 2013, 33, 4802-4808. doi:10.1016/j.msec.2013.07.047

97. Madane, R. G.; Mahajan, H. S. Drug Delivery 2016, 23, 1326-1334. doi:10.3109/10717544.2014.975382

98. Dhule, S. S.; Penfornis, P.; He, J.; Harris, M. R.; Terry, T.; John, V.; Pochampally, R. Mol. Pharmaceutics 2014, 11, 417-427. doi:10.1021/mp400366r

99. Dhule, S. S.; Penfornis, P.; Frazier, T.; Walker, R.; Feldman, J.; Tan, G.; He, J.; Alb, A.; John, V.; Pochampally, R. Nanomedicine (N. Y., NY, U. S.) 2012, 8, 440-451. doi:10.1016/j.nano.2011.07.011

100.Zhang, T.; Chen, Y.; Ge, Y.; Hu, Y.; Li, M.; Jin, Y. Acta Pharm. Sin. B 2018, 8, 440-448. doi:10.1016/j.apsb.2018.03.004

101.Singh, S. P.; Alvi, S. B.; Pemmaraju, D. B.; Singh, A. D.; Manda, S. V.; Srivastava, R.; Rengan, A. K. Int. J. Biol. Macromol. 2018, 110, 375-382. doi:10.1016/j.ijbiomac.2017.11.163

102.Jose, A.; Labala, S.; Ninave, K. M.; Gade, S. K.; Venuganti, V. V. K. AAPS PharmSciTech 2018, 19, 166-175. doi:10.1208/s12249-017-0833-y

103. Thakur Choudhury, S.; Das, N.; Ghosh, S.; Ghosh, D.; Chakraborty, S.; Ali, N. Int. J. Nanomed. 2016, 2179. doi:10.2147/ijn.s101886

104.Xu, M.; Asghar, S.; Dai, S.; Wang, Y.; Feng, S.; Jin, L.; Shao, F.; Xiao, Y. Int. J. Biol. Macromol. 2019, 134, 1002-1012. doi:10.1016/j.ijbiomac.2019.04.201

105.Wang, Y.; Luo, Z.; Wang, Z.; You, M.; Xie, S.; Peng, Y.; Yang, H. J. Nanopart. Res. 2018, 20, 283. doi:10.1007/s11051-018-4382-4 106. Orunoğlu, M.; Kaffashi, A.; Pehlivan, S. B.; Şahin, S.; Söylemezoğlu, F.; Oğuz, K. K.; Mut, M. Mater. Sci. Eng., C 2017, 78, 32-38. doi:10.1016/j.msec.2017.03.292

107. Chaurasia, S.; Chaubey, P.; Patel, R. R.; Kumar, N.; Mishra, B. Drug Dev. Ind. Pharm. 2016, 42, 694-700. doi:10.3109/03639045.2015.1064941 
108.Udompornmongkol, P.; Chiang, B.-H. J. Biomater. Appl. 2015, 30, 537-546. doi:10.1177/0885328215594479

109.Zhao, Y.; Lin, D.; Wu, F.; Guo, L.; He, G.; Ouyang, L.; Song, X.; Huang, W.; Li, X. Int. J. Mol. Sci. 2014, 15, 17565-17576. doi:10.3390/ijms151017565

110.Li, H.; Yan, L.; Tang, E. K. Y.; Zhang, Z.; Chen, W.; Liu, G.; Mo, J. Front. Pharmacol. 2019, 10, 769. doi:10.3389/fphar.2019.00769

111. Guerrero, S.; Inostroza-Riquelme, M.; Contreras-Orellana, P.; Diaz-Garcia, V.; Lara, P.; Vivanco-Palma, A.; Cárdenas, A.; Miranda, V.; Robert, P.; Leyton, L.; Kogan, M. J.; Quest, A. F. G.; Oyarzun-Ampuero, F. Nanoscale 2018, 10, 22612-22622. doi:10.1039/c8nr06173d

112. Inostroza-Riquelme, M.; Vivanco, A.; Lara, P.; Guerrero, S.; Salas-Huenuleo, E.; Chamorro, A.; Leyton, L.; Bolaños, K.; Araya, E.; Quest, A. F. G.; Kogan, M. J.; Oyarzun-Ampuero, F. Molecules 2018, 23, 1208. doi:10.3390/molecules23051208

113. Hong, J.; Liu, Y.; Xiao, Y.; Yang, X.; Su, W.; Zhang, M.; Liao, Y.; Kuang, H.; Wang, X. Drug Delivery 2017, 24, 109-120. doi:10.1080/10717544.2016.1233589

114.Guan, Y.-b.; Zhou, S.-y.; Zhang, Y.-q.; Wang, J.-I.; Tian, Y.-d.; Jia, Y.-y.; Sun, Y.-j. J. Huazhong Univ. Sci. Technol., Med. Sci. 2017, 37, 371-378. doi:10.1007/s11596-017-1742-8

115. Ganta, S.; Devalapally, H.; Amiji, M. J. Pharm. Sci. 2010, 99, 4630-4641. doi:10.1002/jps.22157

116. Mannava, M.; Suresh, K.; Kumar Bommaka, M.; Bhavani Konga, D.; Nangia, A. Pharmaceutics 2018, 10, 7 doi:10.3390/pharmaceutics10010007

117. Desai, P. P.; Patravale, V. B. J. Pharm. Sci. 2018, 107, 1143-1156. doi:10.1016/j.xphs.2017.11.014

118. Vijayakumar, A.; Baskaran, R.; Baek, J.-H.; Sundaramoorthy, P.; Yoo, B. K. AAPS PharmSciTech 2019, 20, 88. doi:10.1208/s12249-019-1295-1

119. Aditya, N. P.; Shim, M.; Lee, I.; Lee, Y.; Im, M.-H.; Ko, S. J. Agric. Food Chem. 2013, 61, 1878-1883. doi:10.1021/jf305143k

120.Xiao, B.; Si, X.; Han, M. K.; Viennois, E.; Zhang, M.; Merlin, D. J. Mater. Chem. B 2015, 3, 7724-7733. doi:10.1039/c5tb01245g

121. Misra, R.; Sahoo, S. K. Mol. Pharmaceutics 2011, 8, 852-866. doi:10.1021/mp100455h

122.Sahu, B. P.; Hazarika, H.; Bharadwaj, R.; Loying, P.; Baishya, R.; Dash, S.; Das, M. K. Expert Opin. Drug Delivery 2016, 13, 1065-1074. doi:10.1080/17425247.2016.1182486

123.Shukla, P.; Mathur, V.; Kumar, A.; Khedgikar, V.; Teja, B. V.; Chaudhary, D.; Kushwaha, P.; Bora, H. K.; Konwar, R.; Trivedi, R.; Mishra, P. R. J. Biomed. Nanotechnol. 2014, 10, 3381-3391. doi:10.1166/jbn.2014.1912

124.Ganta, S.; Amiji, M. Mol. Pharmaceutics 2009, 6, 928-939. doi:10.1021/mp800240

125.Sun, M.; Zhang, Y.; He, Y.; Xiong, M.; Huang, H.; Pei, S.; Liao, J.; Wang, Y.; Shao, D. Colloids Surf., B 2019, 180, 313-318. doi:10.1016/j.colsurfb.2019.04.061

126.Jardim, K. V.; Palomec-Garfias, A. F.; Andrade, B. Y. G.; Chaker, J. A.; Báo, S. N.; Márquez-Beltrán, C.; Moya, S. E.; Parize, A. L.; Sousa, M. H. Mater. Sci. Eng., C 2018, 92, 184-195. doi:10.1016/j.msec.2018.06.039

127.Baghbani, F.; Chegeni, M.; Moztarzadeh, F.; Hadian-Ghazvini, S.; Raz, M. Mater. Sci. Eng., C 2017, 74, 186-193. doi:10.1016/j.msec.2016.11.107

128.Lu, C.-H.; Lin, S.-H.; Hsieh, C.-H.; Chen, W.-T.; Chao, C.-Y. OncoTargets Ther. 2018, 11, 4723-4732. doi:10.2147/ott.s166264
129. Kanagarajan, S. V.; Thiyagarajan, D. Mater. Res. Express 2019, 6, 016105. doi:10.1088/2053-1591/aadc94

130. Purushothaman, B. K.; S, M. H.; Maheswari, P. U.; Begum, K. M. M. S. J. Drug Delivery Sci. Technol. 2019, 52, 509-520. doi:10.1016/j.jddst.2019.05.010

131. Cardoso, B. D.; Rio, I. S. R.; Rodrigues, A. R. O.; Fernandes, F. C. T.; Almeida, B. G.; Pires, A.; Pereira, A. M.; Araújo, J. P.; Castanheira, E. M. S.; Coutinho, P. J. G. R. Soc. Open Sci. 2018, 5, 181017. doi:10.1098/rsos.181017

132. Yallapu, M. M.; Othman, S. F.; Curtis, E. T.; Bauer, N. A.; Chauhan, N.; Kumar, D.; Jaggi, M.; Chauhan, S. C. Int. J. Nanomed. 2012, 7, 1761-1779. doi:10.2147/ijn.s29290

133.Song, W.; Su, X.; Gregory, D. A.; Li, W.; Cai, Z.; Zhao, X. Nanomaterials 2018, 8, 907. doi:10.3390/nano8110907

134.Cui, Y.; Zhang, M.; Zeng, F.; Jin, H.; Xu, Q.; Huang, Y. ACS Appl. Mater. Interfaces 2016, 8, 32159-32169. doi:10.1021/acsami.6b10175

135. Yallapu, M. M.; Ebeling, M. C.; Khan, S.; Sundram, V.; Chauhan, N.; Gupta, B. K.; Puumala, S. E.; Jaggi, M.; Chauhan, S. C. Mol. Cancer Ther. 2013, 12, 1471-1480. doi:10.1158/1535-7163.mct-12-1227

136.Justin, C.; Samrot, A. V.; P., D. S.; Sahithya, C. S.; Bhavya, K. S.; Saipriya, C. PLoS One 2018, 13, e0200440. doi:10.1371/journal.pone.0200440

137.Xing, H.; Wang, Z.; Shao, D.; Chang, Z.; Ge, M.; Li, L.; Wu, M.; Yan, Z.; Dong, W. RSC Adv. 2018, 8, 30448-30454. doi:10.1039/c8ra05694c

138. Barick, K. C.; Ekta, E.; Gawali, S. L.; Sarkar, A.; Kunwar, A.; Priyadarsini, K. I.; Hassan, P. A. RSC Adv. 2016, 6, 98674-98681. doi:10.1039/c6ra21207g

139. Ahn, J.-C.; Kang, J.-W.; Shin, J.-I.; Chung, P.-S. Int. J. Oncol. 2012, 41, 2184-2190. doi:10.3892/ijo.2012.1661

140. Rahimi-Moghaddam, F.; Sattarahmady, N.; Azarpira, N. J. Biomed. Phys. Eng. 2019, 9, 473-482. doi:10.31661/jbpe.v0i0.906

141.Zhu, F.; Tan, G.; Jiang, Y.; Yu, Z.; Ren, F. Biomater. Sci. 2018, 6, 2905-2917. doi:10.1039/c8bm00691a

142. Dev, A.; Srivastava, A. K.; Choudhury, S. R.; Karmakar, S. RSC Adv. 2016, 6, 95165-95168. doi:10.1039/c6ra20269a

143.Duse, L.; Agel, M. R.; Pinnapireddy, S. R.; Schäfer, J.; Selo, M. A.; Ehrhardt, C.; Bakowsky, U. Pharmaceutics 2019, 11, 282. doi:10.3390/pharmaceutics11060282

144.de Matos, R. P. A.; Calmon, M. F.; Amantino, C. F.; Villa, L. L.; Primo, F. L.; Tedesco, A. C.; Rahal, P. BioMed Res. Int. 2018, 1-11. doi:10.1155/2018/4057959

145.Baghdan, E.; Duse, L.; Schüer, J. J.; Pinnapireddy, S. R.; Pourasghar, M.; Schäfer, J.; Schneider, M.; Bakowsky, U. Eur. J. Pharm. Sci. 2019, 132, 63-71. doi:10.1016/j.ejps.2019.02.025

146. Nelson, K. M.; Dahlin, J. L.; Bisson, J.; Graham, J.; Pauli, G. F.; Walters, M. A. J. Med. Chem. 2017, 60, 1620-1637. doi:10.1021/acs.jmedchem.6b00975 


\section{License and Terms}

This is an Open Access article under the terms of the Creative Commons Attribution License (https://creativecommons.org/licenses/by/4.0). Please note that the reuse, redistribution and reproduction in particular requires that the author(s) and source are credited and that individual graphics may be subject to special legal provisions.

The license is subject to the Beilstein Journal of Nanotechnology terms and conditions: (https://www.beilstein-journals.org/bjnano/terms)

The definitive version of this article is the electronic one which can be found at:

https://doi.org/10.3762/bjnano.12.78 